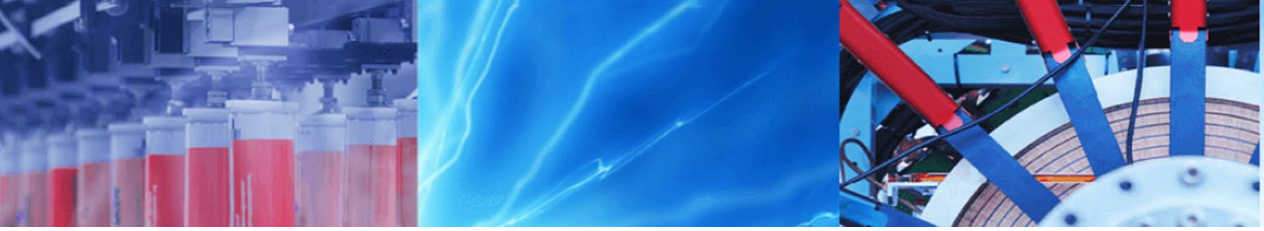

Research Article

\title{
Citrus sinensis peel waste assisted synthesis of AgNPs: effect of surfactant on the nucleation and morphology
}

\author{
Ohod Mansour Khabeeri ${ }^{1}$. Shaeel Ahmad Al-Thabaiti ${ }^{1} \cdot$ Zaheer Khan $^{1}$
}

Received: 25 August 2020 / Accepted: 29 October 2020 / Published online: 20 November 2020

(c) Springer Nature Switzerland AG 2020

\begin{abstract}
Silver nanoparticles (AgNPs) were synthesized by using Citrus sinensis peel waste extract. Optical images and UV-visible spectroscopy reveals the appearance of yellow to brown-red color and surface plasmon resonance (SPR) band at 400$480 \mathrm{~nm}$, respectively, due to the formation of AgNPs. The stable perfect transparent silver sols were formed in presence of cetyltrimethylammonium bromide (CTAB). The brownish precipitates appeared with sodium dodecyl sulphate (SDS) after $3 \mathrm{~h}$. The nucleation, position of SPR band and intensity depends on the head group nature of cationic and anionic micelles of SDS and CTAB. The as-prepared AgNPs were characterized using conventional techniques such as Fouriertransform infra-red, energy dispersed X-ray detector, scanning electron microscope, transmission electron microscope, and X-ray diffractometer. Zeta potential of CTAB-AgNPs was calculated and found to be stable for ca. 1 week. Molar concentration $\left(3.3 \times 10^{-4} \mathrm{~mol} / \mathrm{L}\right)$ and aggregation number $(607,339.917)$ of DPE-AgNPs were calculated. Ascorbic acid, citric acid and total reducing sugars were estimated in dry and fresh peel extract. Gram positive Staphylococcus aureus and Gram-negative Escherichia coli bacteria shows excellent antibacterial activities toward DPE-AgNPs.
\end{abstract}

Keywords Citrus sinensis $\cdot$ AgNPs $\cdot$ Surfactant $\cdot$ Morphology

\section{Introduction}

Use of different capping agent for the synthesis of metallic nanoparticles have received considerable attention in the past two decades, which exhibit different size, shape, optical, catalytic, water treatment, and sensing properties in the field of chemical, physical and medical sciences [1-4]. Due to presence of sharp SPR band, fabrication of AgNPs have been the research interest of various scientists in nanotechnology by using different chemical and physical methods $[5,6]$. Most of these methods required the necessity of toxic non-biodegradable polymers, surfactants, ligands and organic solvents [7-10]. Yin et al. used chemical reduction method for the synthesis of AgNPs with Tollens' reagent (complex of silver ions with ammonia), sodium borohydride, sorbitol, and formaldehyde [11].
Yao et al. synthesized AgNPs by using grape seed and use as catalyst for the degradation of toxic dye [12]. Transition metal NPs have been fabricated form various parts of natural plants such as leaf $[13,14]$, fruit $[15,16]$, stem [17], roots [18], flower [19] and others sustainable low cost and eco-friendly natural materials [20,21]. The bioorganic materials of natural resources acted as capping and reducing agent, which control aggregation and agglomerations of the NPs [22-24].

Citrus sinensis (orange) is one of the most popular fruit has been used around the word, the main world producers of orang fruit are Brazil, China and the USA [25]. As the result, there are millions of tons of orange peel waste have been throwaway. Orange peel contains soluble sugars, pectin, insoluble polysaccharides, polyphenols, amino acids, citric acid and ascorbic acid, and other biomolecules

Zaheer Khan, drkhanchem@yahoo.co.in | 'Department of Chemistry, Faculty of Science, King Abdulaziz University, P.O. Box 80203, Jeddah 21589, Saudi Arabia. 
$[26,27]$. Orange peel also contains large amount of moisture ( $80-90 \% \mathrm{w} / \mathrm{w}$ of water content). So, the investigators reused these wastes of orange to synthesis metal NPs which acted as reducing and stabilizing agents [28-32]. For example, Amanulla et al. used orange peel extract to the synthesis of $\mathrm{TiO}_{2}$ NPs from titanium tetra chloride-redox reaction [28]. Omran et al. recycling the orange peel wastes for the eco-friendly and low cost preparation of AgNPs [30]. Kaviya and his coworkers reported the use of orange peel extract as a reducing agent for the synthesis of AgNPs and evaluated the antibacterial activity of against human pathogens [31]. Various investigators such as Barros et al. [33], Skiba et al. [34], and Awad et al. [35] used orange peel waste extract as reducing agent for the biogenic synthesis of AgNPs, and evaluated their antibacterial and catalytic activities against human pathogens and methylene blue under solar irradiation respectively. Soto and his co-workers utilized fruits peel for the preparation of AgNPs and determined their antimicrobial activities against foodborne pathogens [36]. Rangayasami et al. [37], Aswini et al. [38], Gavade et al. [39], and Gawade et al. [40] used Lindau leaf extract, Ledebouria Revoluta bulb extract, Ziziphus jujuba leaf extract, and Calotropis procera leaves for the fabrication of Ag and ZnNPs for various biological and photocatalytic applications, respectively.

Various stabilizers such as carbohydrates, lipids, organic solvents, proteins, polymers, polyphenols, and surfactant were used to control the morphology of metal NPs (from cubes, hollow structures, disks, multi-branched to multiponds) $[1,8,15,28,41,42]$. Radhika et al. [43] and Kannan et al. [44] were prepared $\mathrm{La}-\mathrm{Sr}-\mathrm{Co}-\mathrm{Fe}-\delta$, and Co-doped rare-earth-based ceria nanocomposites by using cetyltrimethylammonium bromide (CTAB) as a capping agent. Ceria based (Sm doped-CGO) nanocomposite was also synthesized by chemical precipitation method for electrolytic applications [45]. Out of these, CTAB surfactant has been considered as a best capping agent for the synthesis of advanced AgNPs having different morphology [46]. CTAB also tuned the plasmonic properties of AgNPs [47]. Kannangara et al. reported the synthesis of nano zeolite-A with using sodium dodecyl sulphate (SDS) for controlling the particle size and as a site directing agent and it gives a particle with phase with high degree of crystallinity [48]. Das et al. reported the effect of cationic CTAB surfactant on optical, dielectric and magnetic properties of cobalt ferrite NPs, and they also suggested that the CTAB reduces the particle size and enhanced the coactivity as well as remnant ratio of cobalt ferrite NPs [49]. Phuruangrat et al. used $\mathrm{NaBH}_{4}$ as a reducing agent for the synthesis of $\mathrm{Ag} / \mathrm{Bi}_{2} \mathrm{WO}_{6}$ nanoplates and $\mathrm{Ag} / \mathrm{Bi}_{2} \mathrm{MoO}_{6}$ nanocomposites and determined their photocatalytic activities against rhodamine $B$ toxic dye degradation $[50,51]$. It has been established that the different kind of surfactant significantly reduce the particle size without changing the shape. The size reducing ability is not same for all the surfactants, depending on the type of surfactant. However, the use of $C$. sinensis peel wastes as a reducing agent for the synthesis AgNPs has been ignored in presence of shape-controlling surfactants.

Therefore, the aim of this present study was to evaluate the role of surfactant on the morphology of $C$. sinensis peel wastes assisted synthesis of AgNPs. For this purpose, dry peel extract (DPE), and fresh peel extract (FPE) were prepared in water and used as a reducing agent with different concentrations for the preparation of AgNPs. CTAB and SDS were used as capping agent to determine the path of reduction of $\mathrm{Ag}^{+}$ions into metallic silver.

\section{Experimental}

\subsection{Materials}

Citrus sinensis (sweet orange) was collected from local grocery store, washed, and took out jest the peel. For extract preparation, peel was dried for many days at room temperature. The $15 \mathrm{~g}$ powder of the dry orange peel was taken in a conical flask, add $250 \mathrm{~mL}$ deionized double distilled water, heated for $30 \mathrm{~min}$ under $60^{\circ} \mathrm{C}$, the solution could cool down to room temperature and filtered with Whatman filter paper No. 1. The resulting filtrate was stored in amber colored glass container in dark and labeled as DPE. The $15 \mathrm{~g}$ of fresh orange peel was also used for the preparation of extract under similar conditions and designated as FPE. Silver nitrate (molar mass $=169.87,99.9 \%$ ) solution $(0.01 \mathrm{~mol} / \mathrm{L}$ in $250 \mathrm{~mL})$ was prepared in deionized double distilled water and stored in an amber glass container to prevent the photochemical reduction of $\mathrm{Ag}^{+}$ions. CTAB (molecular weight $=364.45 \mathrm{~g}$ per mol; Fluka, 99.9\%) and SDS (molecular weight $=288.372 \mathrm{~g}$ per mol, $99.9 \%$ SigmaAldrich) solutions were prepared in deionized water and used as a stabilizer and/or capping agent.

\subsection{Citrus sinensis peel extract assisted of AgNPs}

DPE and FPE were used as a green reducing agent for the synthesis of AgNPs. The DPE $(5.0 \mathrm{~mL})$ was added into a series of conical flask containing different concentrations of $\mathrm{AgNO}_{3}$ solution (ranging from 2.0 to $10.0 \mathrm{~mL}$ of $0.01 \mathrm{~mol} / \mathrm{L}$ ) and diluted with deionized water for fixed the volume constant. The total volume was maintained constant $(50 \mathrm{~mL})$ for all experiments. For the next experiments, the same concentration of $\mathrm{AgNO}_{3}(1.0 \mathrm{mM})$ was added into the solution containing different amount of DPE (from 10 to 50\%). The resulting reaction mixtures were stirred at room temperature with constant stirring. To determine the effects of stabilizers, the $5.0 \mathrm{~mL}$ of DPE was 
mixed with $\mathrm{AgNO}_{3}(1.0 \mathrm{mM})$ in different reaction vessel containing CTAB (from $4.0 \times 10^{-4}$ to $10.0 \times 10^{-4} \mathrm{~mol} / \mathrm{L}$ ) and SDS $\left(4.0 \times 10^{-3}\right.$ to $\left.10.0 \times 10^{-3} \mathrm{~mol} / \mathrm{L}\right)$ solutions. The colorless solutions became pale yellow, yellow to red orange red with increasing reaction time due to the formation of AgNPs [36]. The progress of reaction was monitored by recording SPR absorbance on a UV-visible spectroscopy (Shimadzu UV-visible multi Spec-1501). UV-Vis spectra were recorded at different time intervals in the wavelength ranging from 200 to $800 \mathrm{~nm}$. The same experiments were performed with FPE with same concentrations of $\mathrm{Ag}^{+}$ions, CTAB and SDS at room temperature.

\subsection{Characterization of NPs}

UV-visible (UV-Vis, Shimadzu UV-visible multi Spec1501) spectrophotometer was used for the measurement of spectra having $1 \mathrm{~cm}$ quartz cuvettes at different time intervals. Scanning electron microscope (SEM), transmission electron microscope (TEM, JEM 2100), equipped with energy dispersed X-ray detector (EDX), and Burker Tensor Fourier-transform infra-red (FTIR) instrument were used to determine the morphology of as-prepared AgNPs and capping action of surfactant with NPs. Rigaku X-ray diffractometer (XRD) operating at $40 \mathrm{kV}$ with Ni filtered $\mathrm{Cu} \mathrm{K}_{\mathrm{a}}$ radiation $(\lambda=1.54056)$ were used to determine the crystalline nature of metallic silver. For TEM measurements, the one or two drop of silver sols was placed on the surface of carbon coated copper grid and the solvent was evaporated at room temperature before the experiment. $\mathrm{The} \mathrm{KBr}$ disk was prepared by dropping resulting sols on the surface of pellet and dried in air before recording FTIR spectra. The aqueous suspensions of AgNPs were centrifuged for 30 min and solid AgNPs was washed with distilled water and dry at room temperature before the measurement of SEM. Fisher Scientific $\mathrm{pH}$ meter used to monitor the $\mathrm{pH}$ at the beginning as well as end of the reaction.

\subsection{Estimation of biomolecules in C. sinensis peel extract}

Water soluble constituents of $C$. sinensis peel extract were responsible to the reduction of colorless $\mathrm{Ag}^{+}$ions into dark yellow to red orange silver sols. Ascorbic acid, citric acid and water-soluble sugars were determined with standard methods in both DPE and FPE. Spectroscopic and titration methods were used to determine the concentration of ascorbic and citric acid in C. sinensis peel extract [52, 53]. Klein and Perry spectroscopic method was used for the quantitative estimation of ascorbic acid with slight modification [52]. In a typical experiment, the $5 \mathrm{~g}$ dry peel was mixed with required amount of metaphosphoric acid $(5 \%, 20 \mathrm{~mL})$, stirred for $30 \mathrm{~min}$ at room temperature and filtered. The extract was treated with 2, 6-dichloroindophenol and the absorbance of resulting color was measured at $515 \mathrm{~nm}$. A calibration curve (absorbance versus ascorbic acid concentration) was prepared for standard solution of authentic sample of ascorbic acid with 2, 6-dichloroindophenol and amount of ascorbic acid was calculated form the calibration graph. Titration methods were employed to determine the concentrations of ascorbic and citric acids in peel extract. For ascorbic acid estimation, the DPE was titrated with potassium periodate $\left(\mathrm{KIO}_{4}\right)$ in presence of starch as an indicator [54]. For citric acid, the extract was titrated against standard $\mathrm{NaOH}$ solution using phenolphthalein as an indicator. The results are given in $\mu \mathrm{g}$ of ascorbic and citric acid in per $\mathrm{g}$ of extract. Water soluble reducing sugars were estimated by using dinitrosalicylic acid color test method. Glucose was used as a standard for the construction of calibration curve by measuring the absorbance at $575 \mathrm{~nm}$. The dissolved molecular oxygen gas was removed with bubbling pure nitrogen gas through the reaction test [54].

\subsection{Calculation of molar concentration and number of silver atoms}

The number of silver atoms NPs $(\mathrm{N})$ and molar concentration (C) of NPs were calculated by using the following relations (Eqs. 1 and 2) for the 100\% reduction of silver ions into metallic silver.

$N=\frac{\pi \rho N_{A}}{6 M} \times D^{3}$

$C=\frac{N_{T}}{N V N_{A}}$

where $N, \rho, N_{A}, D$ and $M$ are the aggregation number of AgNPs, density of metallic silver $\left(10.5 \mathrm{~g} / \mathrm{cm}^{3}\right)$, Avogadro's number $\left(6.02 \times 10^{23}\right)$, average diameter of AgNPs and atomic mass of silver (107.86 g), respectively. $\mathrm{N}_{\mathrm{T}}$ and $\mathrm{V}$, respectively, are the total silver atoms used as $\mathrm{AgNO}_{3}$ and volume of the reaction mixture in liter $(0.05 \mathrm{~L})$.

\subsection{Antibacterial activities of AgNPs}

Antibacterial activities of DPE-AgNPs were determined by using turbidity kinetic method against Gram-positive Staphylococcus aureus and Gram-negative Escherichia coli [55]. In a typical experiment, the cultured bacterial cells were added into the separates reaction vessel containing the required amount of DPE-AgNPs (ranging from $10.0 \times 10^{-5}$ to $40.0 \times 10^{-5} \mathrm{~mol} / \mathrm{L}$ ). The progress of growth of bacterial (killing kinetics), was monitored by recording the decay of absorbance at $600 \mathrm{~nm}$ as a function of time. 
The growth rate constants were calculated with first order rate-law $\left(\right.$ rate $=2.303 / \mathrm{t}\left(\log \left(\mathrm{OD}_{\mathrm{a}}-\mathrm{OD}_{0} / \mathrm{OD}_{\mathrm{a}}-\mathrm{OD}_{\mathrm{t}}\right)\right)$, where $O D$ is the optical density at final, initial, and different time intervals at $600 \mathrm{~nm}$ ). The gentamicin was used as standard inhibition control.

\section{Results and discussion}

\subsection{Fresh peel extract assisted synthesis of AgNPs}

Preliminary observations indicate that the yellow to dark red color was developed in a reaction mixture containing same amount of $\mathrm{AgNO}_{3}(5.0 \mathrm{~mL}$ of $0.01 \mathrm{~mol} / \mathrm{L})$ and different amount of FPE. At higher extract concentration $(\geq 60 \%)$, dark yellow-red precipitate was formed instead of perfect transparent color. The resulting silver sols were unstable. To determine the stability of AgNPs, a series of experiments were performed with varying FPE concentration from (10\% to $50 \%$ ) at fixed concentration of $\mathrm{AgNO}_{3}$ $(5.0 \mathrm{~mL}$ of $0.01 \mathrm{~mol} / \mathrm{L}=1.0 \mathrm{mM})$ at $30^{\circ} \mathrm{C}$. The colorless reaction solution containing peel extract and $\mathrm{AgNO}_{3}$ became pale yellow with reaction time, indicating the reduction of $\mathrm{Ag}^{+}$ions into metallic silver [46]. UV-visible spectra of resulting color were recorded as a function of time. Figure 1 shows the effect of FPE on the growth of AgNPs for different concentration. FPE shows an absorption peak at ca. $400 \mathrm{~nm}$ and spectra was featureless in the entire visible region (Fig. 1a, red line). A broad shoulder starts to develop at $450 \mathrm{~nm}$, intensity increases with time and blue shifted from 450 to $465 \mathrm{~nm}$, which might be due to the formation of AgNPs. The peak intensity of FPE was decreased with time at $400 \mathrm{~nm}$, suggesting the role of water soluble chemical constituents (mainly ascorbic acid) of peel extract as reducing agent. Inspection of Fig. 1a-e clearly shows that the SPR intensity of broad shoulder at $450 \mathrm{~nm}$ increases with increasing concentration of FPE from 10 to $40 \%$ with a red shift and decreases for $50 \%$ FPE (Fig. 1e). At higher concentration, decrease in the SPR intensity might be due to the adsorption of FPE active constituents on the surface of AgNPs. Reaction-time profile (absorbance versus time) plots indicate that the all process (nucleation, growth, and stabilization) decreases with increasing the FPE concentration (Fig. 2).

\subsection{Role of stabilizers}

It is well known that the presence of a suitable stabilizer is essential to block the unlimited growth of metal NPs. To establish the role of stabilizers and to prepare stable silver sols at room temperature, two surfactants, CTAB and SDS were used as capping agent. UV-visible spectra of the mixture were recorded with different time intervals.
SPR intensity starts to develop in the visible region with increasing reaction time (Table 1). A broad shoulder was appeared at ca. $500 \mathrm{~nm}$ after $24 \mathrm{~h}$. Inspection of Fig. 3a shows that the resulting silver sol exhibited a well-defined SPR band after $48 \mathrm{~h}$ and shape of the spectra depends on the reaction time. The same experiment was also performed with SDS $(2.0 \mathrm{~mL}$ of $0.1 \mathrm{~mol} / \mathrm{L})$. Figure $3 \mathrm{~b}$ shows the effect of reaction time on the formation of SDS-AgNPs. The resulting sols exhibited broad SPR shoulder in the entire visible region. The growth spectra of CTAB and SDS assisted AgNPs were different for both surfactants, which clearly explains the different stabilizing and/or capping action of surfactant [9]. Optical images of extract, CTAB and SDS-AgNPs indicate that the resulting sols are unstable in presence of SDS. The yellowish turbidity appeared within 120 min for SDS-AgNPs. Interestingly, CTAB-AgNPs (red orange color) was stable for ca. $24 \mathrm{~h}$ and no precipitate or turbidity was appeared (Scheme 1), which might be due to the capping action of CTAB micelles. CTAB stabilized the AgNPs and blocked the unlimited growth of NPs. As a result, prefect transparent of AgNPs were formed in presence of CTAB.

\subsection{Dry peel extract assisted synthesis of AgNPs}

To compare the reactivity of DPE with FPE towards $\mathrm{AgNO}_{3}$ interaction, same experiments were performed with DPE and $\mathrm{AgNO}_{3}$ with and without CTAB and SDS (Table 1). To determine the effect of DPE concentration on the stability of AgNPs formation, a series of kinetic experiments were performed fixed concentration of $\mathrm{AgNO}_{3}$ and varying concentrations of DPE from 10 to $40 \%$. At higher DPE concentration ( $\geq 50 \%)$, the resulting silver sols were unstable and yellowish precipitate was formed due to the uncontrolled agglomeration process. UV-visible spectra were recorded as a function of time to the formation of silver NPs. Figure 4 shows the that the resulting silver sol exhibited a well-defined SPR band in the $400-500 \mathrm{~nm}$ within $5 \mathrm{~min}$ of reaction time. The reduction of $\mathrm{Ag}^{+}$into $\mathrm{Ag}^{0}$ was fast and resulting sols show a SPR band at $468 \mathrm{~nm}$ after $5 \mathrm{~min}$ for extract stabilized AgNPs. The SPR intensity increased and decreased with time due to the uncontrolled capping action of extract but position of band remains constant for entire reaction time (Fig. 4a).

To determine the effect of surfactant, the lower DPE concentration (10\%) was used for the entire studied. For CTAB-AgNPs $([C T A B]=1.0 \mathrm{mM})$, a band was appeared at $418 \mathrm{~nm}$ (Fig. 4b). The resulting sol shows SPR band at $477 \mathrm{~nm}$ for SDS-AgNPs (Fig. 4c), which indicates the formation of larger size AgNPs. These results revealed that the SPR intensity, and band position depends on the reaction parameters such as reaction time, concentration of reducing and stabilizing agent. Inspection of these results 

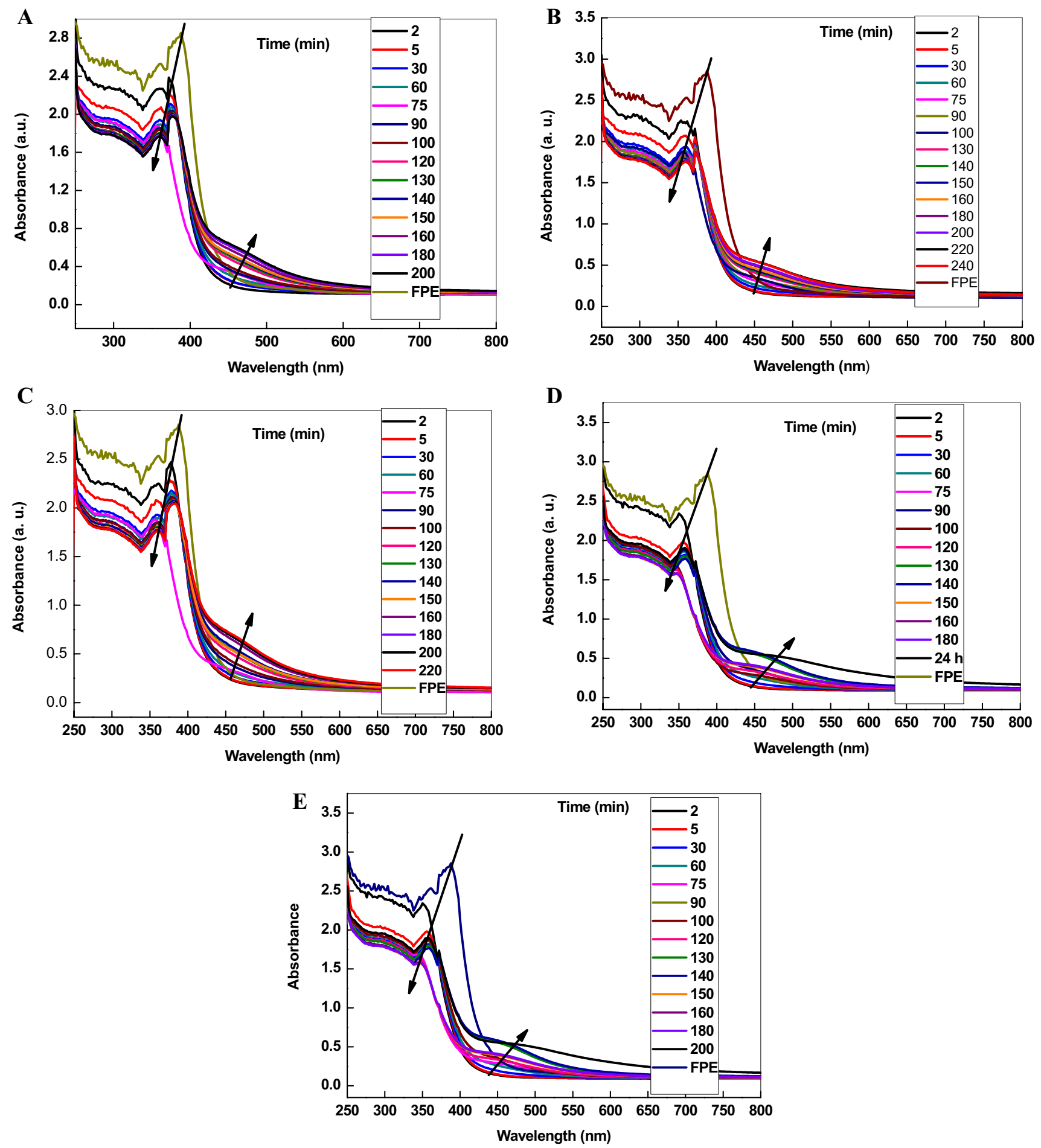

Fig. 1 Time resolved UV-visible spectra of AgNPs formation with varying concentration of DPE. Reaction conditions: $\left[\mathrm{Ag}^{+}\right]=1.0 \mathrm{mM}^{\circ}$ $[\mathrm{DPE}]=10(\mathbf{a}), 20(\mathbf{b}), 30(\mathbf{c}), 40(\mathbf{d})$ and $50 \%(\mathbf{e})$, temperature $=30^{\circ} \mathrm{C}$

clearly indicates that the wavelength maxima of AgNPs depend on the nature of capping action of stabilizers (Table 1). The blue (from 468 to $418 \mathrm{~nm}$ ) and red (from 468 to $477 \mathrm{~nm}$ ) shift were observed for CTAB- and SDSAgNPs, which might be due to the different capping and stabilizing role of used surfactant during the nucleation step $\left(\mathrm{Ag}^{+} \rightarrow \mathrm{Ag}^{0}\right)$. It is well known that the fresh C. sinensis peel contained ca. $80-90 \% \mathrm{~W} / \mathrm{w}$ of water, whereas dry peel has $20 \%$ water [56]. Ascorbic acid $(=525 \mu \mathrm{g} / 100 \mathrm{~g}$ extract), citric acid $(=95 \mu \mathrm{g} / 100 \mathrm{~g}$ extract $)$ and reducing sugars 


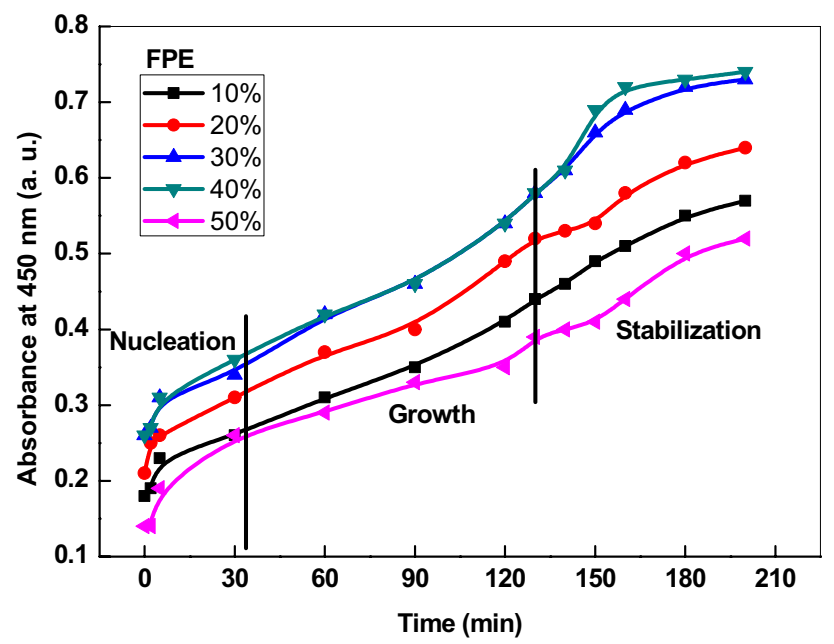

Fig. 2 Reaction-time profiles to the formation of AgNPs for Fig. 1 data

( $=40 \mathrm{mg} / 100 \mathrm{~g}$ extract) were determined in DPE. Due to the high content of water, the same amount of fresh peel has the lower concentration of water soluble reducing agent than that of dried peel. On the other hand, FPE contained ascorbic acid $=50 \mu \mathrm{g} / 100 \mathrm{~g}$ extract. Ascorbic acid is a strong reducing agent than that of reducing sugars and citric acid. The different behaviors of both peel extract (fresh and dry) can be rationalized with the higher concentration of ascorbic acid DPE (Scheme 2), which clearly shows that the reduction of $\mathrm{Ag}^{+}$into $\mathrm{Ag}^{0}$ was completed within ca. $10 \mathrm{~min}$ of the reaction time for the DPE.

\subsection{Capping mechanism of stabilizers}

The aqueous extract of orange peel contained water soluble polyphenols, sugars and organic acids $[25,26,57,58]$. Out of these, ascorbic acid is the major constituents of peel extract in water at room temperature. CTAB and SDS were ionized in aqueous water and formed various aggregates (from monomer, dimer, and trimer to micelles). At critical micellar concentration, these aggregates are called as micelles, which incorporates the water soluble and water insoluble materials into its small volume via electrostatic, hydrophobic, hydrogen bonding and van der Walls forces [59]. The polar ionic head group has significant impact on the solubilization processes. Cationic and anionic head groups of CTAB and SDS micelles, respectively, repelled and attracted the $\mathrm{Ag}^{+}$ions due to electrostatic interactions. lonized SDS formed complex with $\mathrm{Ag}^{+}$ions (Eqs. 3 and 4).

$$
\mathrm{CH}_{3}\left(\mathrm{CH}_{2}\right)_{10} \mathrm{CH}_{2} \mathrm{OSO}_{3} \mathrm{Na} \leftrightarrow \mathrm{CH}_{3}\left(\mathrm{CH}_{2}\right)_{10} \mathrm{CH}_{2} \mathrm{OSO}_{3}^{-}+\mathrm{Na}^{+}
$$

$\mathrm{CH}_{3}\left(\mathrm{CH}_{2}\right)_{10} \mathrm{CH}_{2} \mathrm{OSO}_{3}^{-}+\mathrm{Ag}^{+} \leftrightarrow \mathrm{CH}_{3}\left(\mathrm{CH}_{2}\right)_{10} \mathrm{CH}_{2} \mathrm{OSO}_{3}-\mathrm{Ag}$

The reduction potential of $\mathrm{Ag}^{+} / \mathrm{Ag}^{0}(=0.799 \mathrm{~V})$ was reduced to some extent after complex formation with ionized SDS [60]. This type of situation does not persist in CTAB due to repulsion between $\mathrm{Ag}^{+}$and positive head group $\left(-\mathrm{N}\left(\mathrm{CH}_{3}\right)_{3}{ }^{+}\right)$. Ascorbic acid transfers the electrons to the $\mathrm{Ag}^{+}$, which reduces to metallic $\mathrm{Ag}^{0}$ (Eqs. 5 and 6).
Table 1 Effects of reaction parameters on the morphology of orange peel extract assisted synthesis of AgNPs

\begin{tabular}{|c|c|c|c|}
\hline [FPE] (\%) & {$\left[\mathrm{Ag}^{+}\right](\mathrm{mM})$} & CTAB/SDS & Observations \\
\hline 10 & 1.0 & 0.0 & Pale yellow, $\lambda_{\max }=450 \mathrm{~nm}, 120 \mathrm{~min}$, stable \\
\hline 20 & 1.0 & 0.0 & Pale yellow, $\lambda_{\max }=455 \mathrm{~nm}, 120 \mathrm{~min}$, stable \\
\hline 30 & 1.0 & 0.0 & Pale yellow, $\lambda_{\max }=460 \mathrm{~nm}, 120 \mathrm{~min}$, stable \\
\hline 40 & 1.0 & 0.0 & Pale yellow, $\lambda_{\max }=460 \mathrm{~nm}, 120 \mathrm{~min}$, stable \\
\hline 50 & 1.0 & 0.0 & Pale yellow, $\lambda_{\max }=465 \mathrm{~nm}, 120 \mathrm{~min}$, stable \\
\hline [DPE] (\%) & {$\left[\mathrm{Ag}^{+}\right](\mathrm{mM})$} & CTAB/SDS & Observations \\
\hline 10 & 1.0 & 0.0 & Yellow, $\lambda_{\max }=468 \mathrm{~nm}, 5 \mathrm{~min}$, stable \\
\hline 20 & 1.0 & 0.0 & Yellow, $\lambda_{\max }=468 \mathrm{~nm}, 5 \mathrm{~min}$, stable \\
\hline 30 & 1.0 & 0.0 & Yellow, $\lambda_{\max }=468 \mathrm{~nm}, 5 \mathrm{~min}$, stable \\
\hline 40 & 1.0 & 0.0 & Yellow, $\lambda_{\max }=468 \mathrm{~nm}, 5 \mathrm{~min}$, stable \\
\hline 10 & 1.0 & $0.4 \mathrm{mM}(\mathrm{CTAB})$ & Pale yellow, $\lambda_{\max }=500 \mathrm{~nm}, 5 \mathrm{~min}$, stable \\
\hline 10 & 1.0 & 1.0 & Dark yellow, $\lambda_{\max }=420 \mathrm{~nm}, 5 \mathrm{~min}$, stable \\
\hline 10 & 1.0 & 5.0 & Dark yellow, $\lambda_{\max }=420 \mathrm{~nm}, 5 \mathrm{~min}$, stable \\
\hline 10 & 3.0 & 1.0 & Dark yellow, $\lambda_{\max }=420 \mathrm{~nm}, 5 \mathrm{~min}$, stable \\
\hline 10 & 5.0 & 1.0 & Dark yellow, $\lambda_{\max }=420 \mathrm{~nm}, 5 \mathrm{~min}$, stable \\
\hline 10 & 7.0 & 1.0 & Unstable, yellowish precipitate \\
\hline 10 & 1.0 & 2.0 (SDS) & Pale yellow, $\lambda_{\max }=477 \mathrm{~nm}, 30 \mathrm{~min}$, unstable \\
\hline 10 & 1.0 & 8.0 & Unstable, yellowish precipitate \\
\hline
\end{tabular}



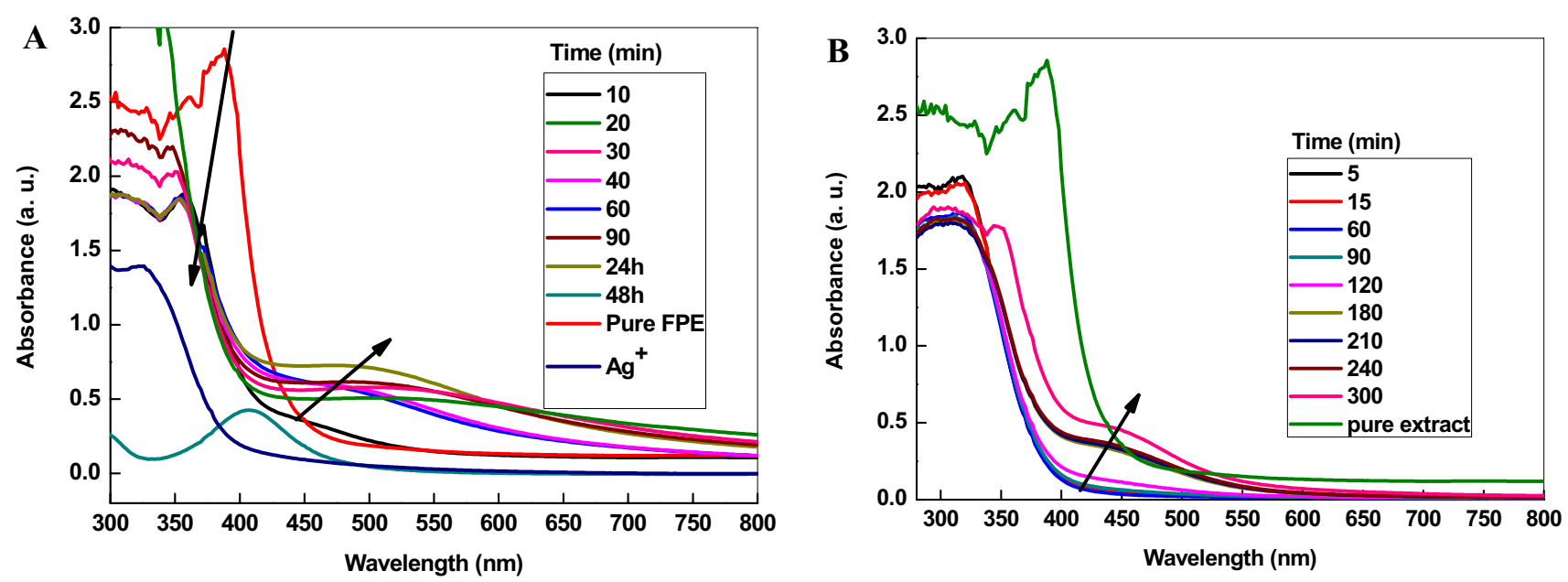

Fig. 3 Time resolved UV-visible spectra of CTAB-AgNPs (a) and SDS-AgNPs (b) formation with FPE. Reaction conditions: $\left[\mathrm{Ag}^{+}\right]=1.0 \mathrm{mM}$, $[\mathrm{FPE}]=10 \%$, temperature $=30^{\circ} \mathrm{C}$

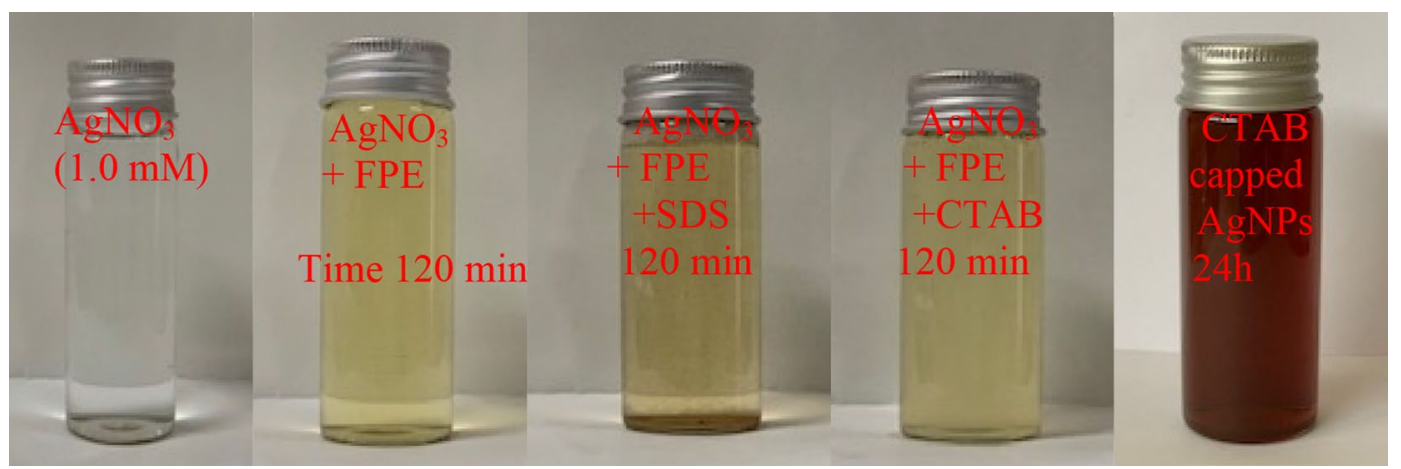

Scheme 1 Optical images of $\mathrm{AgNO}_{3}$, and AgNPs formation with FPE in absence and presence of SDS and CTAB at different time

Ascorbic acid $+\mathrm{Ag}^{+} \rightarrow$ Ascorbate radical $+\mathrm{Ag}^{0}$

Ascorbate radical $+\mathrm{Ag}^{+} \rightarrow$ Dehydro ascorbicacid $+\mathrm{Ag}^{0}$

Metallic silver immediately converted to the stable species of colloidal silver after complexation and dimerization processes (Eqs. 7 and 8) [61].

$\mathrm{Ag}^{0}+\mathrm{Ag}^{+} \rightarrow \mathrm{Ag}_{2}^{+} \quad$ (complex formation)

$\mathrm{Ag}_{2}^{+}+\mathrm{Ag}_{2}^{+} \rightarrow \mathrm{Ag}_{4}^{2+} \quad$ (dimerization)

On the other hand, the surface of silver NPs $\left(\mathrm{Ag}_{4}{ }^{2+}\right)$ is positive [61], which also interacts with the negative head group of SDS micelles. Formation of SD- $\mathrm{Ag}^{+} \mathrm{com}-$ plex delayed the electron gaining tendency of silver ions from the reductant. The larger size silver NPs were formed for the slow redox reaction. As a result, yellowish turbidity was observed with SDS surfactant instead of perfect transparent silver sols formation (Scheme 1). CTAB is a better stabilizing agent than that of SDS [9].

\subsection{Characterization of AgNPs}

Morphology of DPE-AgNPs and CTAB-AgNPs were determined by using TEM, SEM, EDX, FTIR, and XRD measurements. For DPE assisted synthesis of AgNPs, the reaction was completed within ca. 10 min of reaction time in presence of $C T A B$ and resulting silver sols were stable. On the other hand, yellowish turbidity was appeared in presence of SDS. Therefore, samples of DPE-AgNPs and CTAB-AgNPs were prepared for the characterization. TEM images of DPE-AgNPs and CTAB-AgNPs are given in Fig. 4a and b, respectively, with UV-visible spectra. The NPs are spherical with size ranging from 11 to $35 \mathrm{~nm}$ for DPE (Fig. 4a). The NPs are aggregated in an unsymmetrical manner and leads to the formation of necklace-like metallic silver with CTAB having smaller size ranging from 8 to $22 \mathrm{~nm}$ (Fig. $4 \mathrm{~b}$ ). CTAB acted as a stabilizer and adsorbed on the surface of 

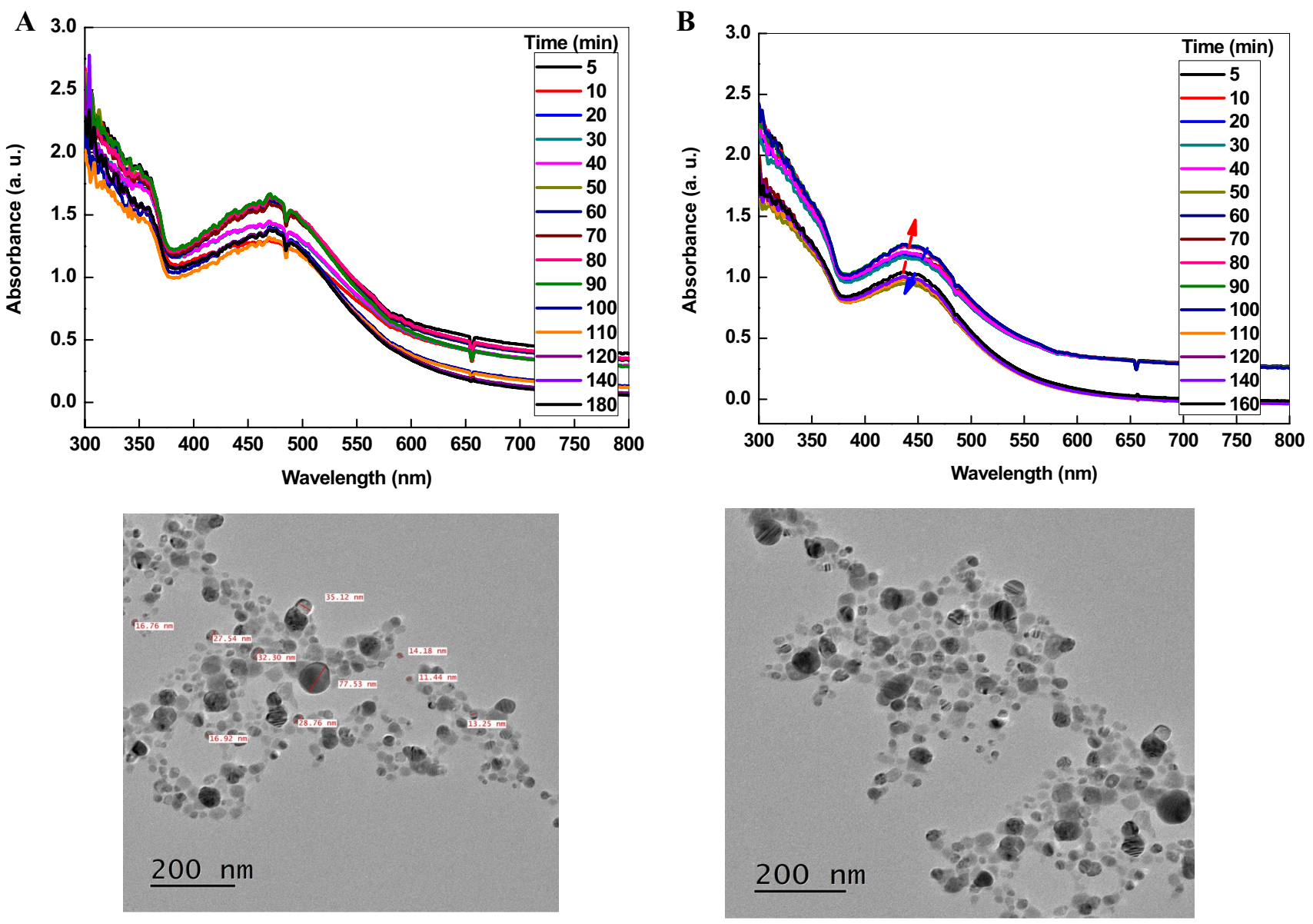

Fig. 4 Time resolved UV-visible spectra and TEM images of DPE-AgNPs (a) and CTAB-AgNPs formation with DPE (b). Reaction conditions: $\left[\mathrm{Ag}^{+}\right]=1.0 \mathrm{mM},[\mathrm{DPE}]=10 \%,[\mathrm{CTAB}]=1.0 \mathrm{mM}$, temperature $=30^{\circ} \mathrm{C}$

AgNPs. Particles are spherical in both cases. Minute black spots were also visualized on the surface of metallic silver, indicating the presence of orange peel biomolecules on the surface of NPs [21,54]. The size distribution curves of DPE-AgNPs and CTAB-AgNPs are given in Fig. $5 a$ and b, respectively.

Figure $6 a$ and $b$ shows the SEM and EDX of DPE-AgNPs and CTAB-AgNPs. These results reveal that the as-prepared AgNPs are spherical and aggregated to each other. Morphology (shape, size, and the size distribution) are different for CTAB-AgNPs than that of DPE-AgNPs. Inspection of EDX spectra clearly indicates that our sample did not contained $\mathrm{N}$ and $\mathrm{Br}$, which might be removal of CTAB during the washing processes (Fig. 6). The presence of $C$ and $O$ might be due to the carbon coated CU TEM grid and sample preparation at room temperature, respectively. EDX indicates that the NPs contained $100 \%$ pure silver content.

To determine the capping nature of CTAB, FTIR spectra were also recorded. Figure 7 shows the FTIR spectra of CTAB-AgNPs and DPE-AgNPs. The main peaks were appeared at 2920, 2880, and $1420 \mathrm{~cm}^{-1}$ are assigned to asymmetric $\mathrm{v}_{(\mathrm{as})}\left(\mathrm{CH}_{3}\right)$, symmetric $\mathrm{v}_{(\mathrm{s})}\left(\mathrm{CH}_{2}\right), \mathrm{v}(\mathrm{C}-\mathrm{N})$ for pure CTAB. For CTAB-AgNPs, the peaks are red shifted and their intensity was also decreased. The peak at $3450 \mathrm{~cm}^{-1}$ for $v_{\text {(as) }}(-\mathrm{OH})$ might be due to the presence of polyphenols and ascorbic acid on the surface of AgNPs. The FTIR spectrum of DPE-AgNPs is depicted in Fig. 7, which shows the presence of two main absorption peaks at ca. 3450 and $1750 \mathrm{~cm}^{-1}$, which assigned to the $v_{\text {(as) }}$ $-\mathrm{OH}$ groups of ascorbic acid of orange peel constituents and carbonyl group as ester-like [62] (Fig. 7, inset).

XRD spectra of CTAB-AgNPs and DPE-AgNPs were recorded to determine the crystalline nature of NPs. XRD spectra of both AgNPs shows the presence of four Bragg peak at $2 \theta$ values of $38.2^{\circ}(111), 44.3^{\circ}(200), 64.5^{\circ}(220)$, and $77.5^{\circ}$ (311) (JCPDS file NO: 89-3722), which indicates that the NPs have face-centered-cubic metallic AgNPs. We did not observe any remarkable shift of all diffraction peaks of CTAB-AgNPs and DPE-AgNPs (Fig. 8). The average size of AgNPs was calculated using (Eq. 9). 

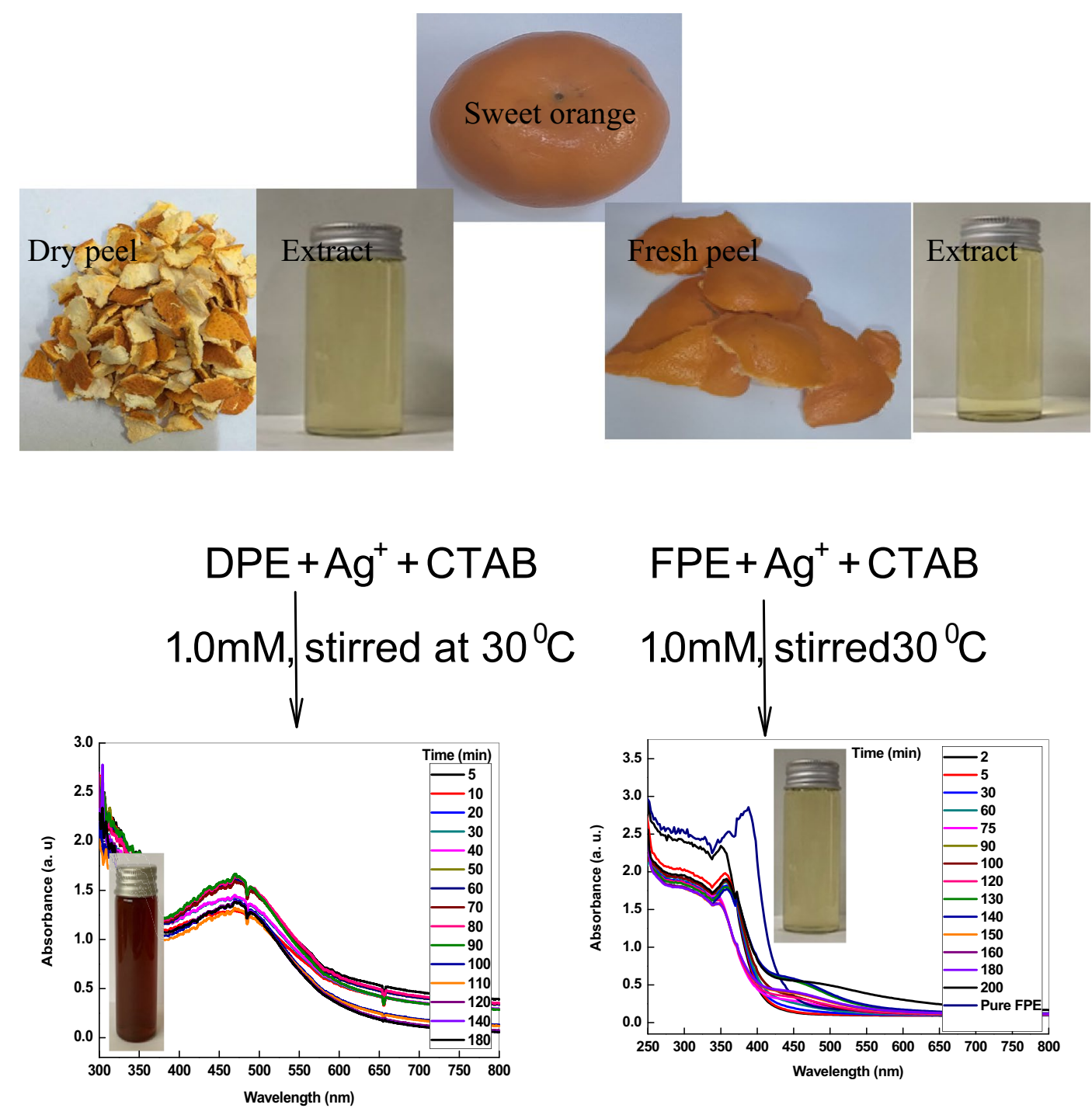

Scheme 2 Effect of DPE and FPE on the nucleation and growth processes of AgNPs formation with CTAB

$D=\frac{k \lambda}{\beta \cos \theta}$

where $D, k$ ( $=0.9$ constant $), \lambda, \beta$, and $\theta$ are the crystallite size of AgNPs, source of $X$-ray radiation $(=0.15406 \mathrm{~nm})$, full width at half maximum of the peak, and Braggs' angle, respectively. The average size of AgNPs was calculated using (Eq. 9). The calculated average particle is found to be $25 \mathrm{~nm}$ and $28 \mathrm{~nm}$ for CTAB-AgNPs and DPE-AgNPs, respectively, for the width of (111) Bragg's refraction.

Zeta potential provides significant information about the stability of NPs. To determine the stability of CTAB-AgNPs, zeta potential (ל) was also calculated with Smoluchowski equation Eq. (10) [63].

$\xi=\frac{4 \eta \pi}{D} \times E M$ where $\eta=$ viscosity of the solvent, $D=$ dielectric constant of the solvent, and EM= electrophoretic mobility. The NPs with zeta potential more negative than $-30 \mathrm{mV}$ and more positive than $+30 \mathrm{mV}$ are stable [24]. The zeta potentials were found to be $-8 \mathrm{mV}$ and $-30 \mathrm{mV}$, respectively, for DPE- and CTAB-AgNPs. The lower value of zeta potential indicates that the DPE-AgNPs are unstable and yellowish turbidity was appeared after $24 \mathrm{~h}$ at room temperature. To determine the stability of CTAB-AgNPs, the zeta potential values were determined for 1 week (Fig. 9). We did not observe any significant change in the value of zeta potential, which shows that the stable AgNPs were formed with CTAB.

The $\mathrm{N}$ was calculated by substituting using the values of $\rho, N_{A}, D$, and $M$ in Eq. (1) The average diameter of AgNPs was calculated by TEM $(20 \mathrm{~nm})$. The molar concentration of AgNPs were calculated with Eq. (2) by substituted the 

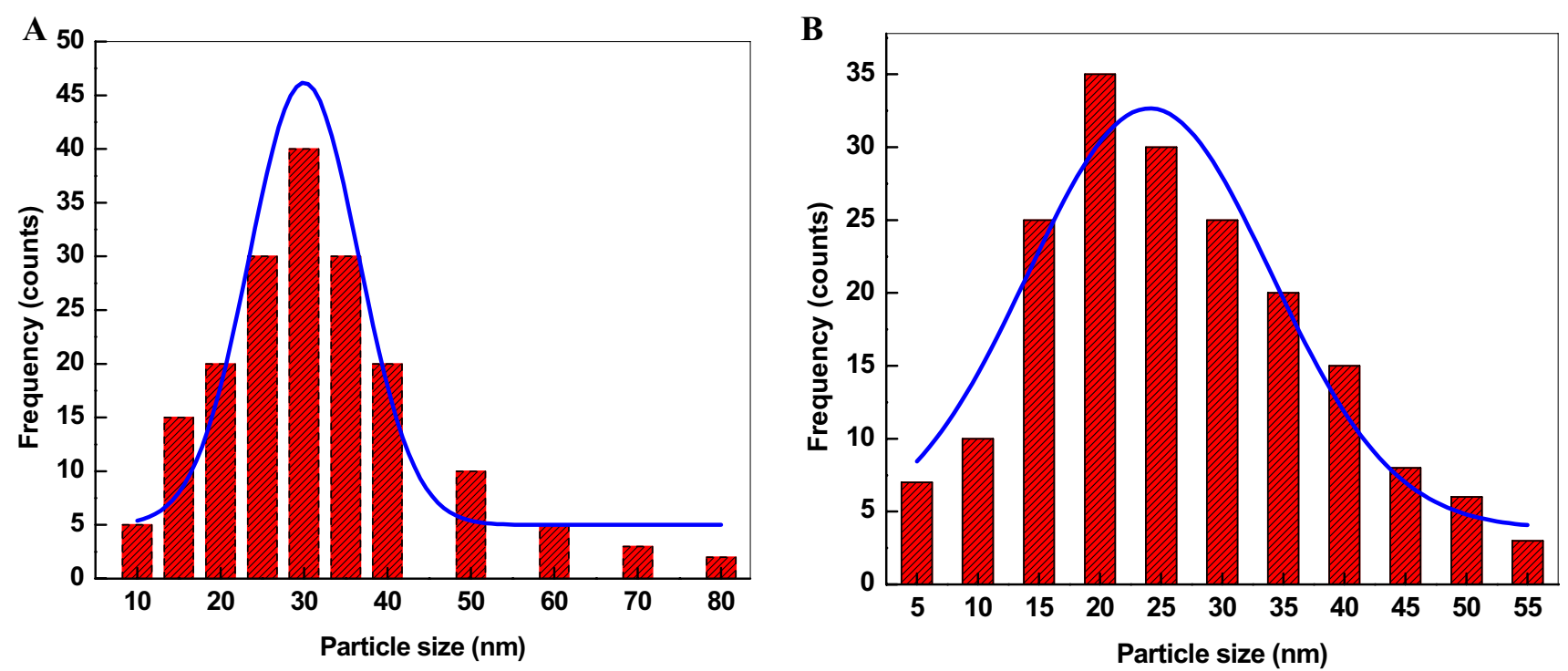

Fig. 5 Size distribution curves of DPE-AgNPs and CTAB-AgNPs. Reaction conditions: $\left[\mathrm{Ag}^{+}\right]=1.0 \mathrm{mM},[\mathrm{CTAB}]=1.0 \mathrm{mM},[\mathrm{DPE}]=10 \%$, temperature $=30^{\circ} \mathrm{C}$

values of $\mathrm{N}_{\mathrm{T}}, \mathrm{N}, \mathrm{V}$ and $\mathrm{N}_{\mathrm{A}}$. The calculated values of average diameter, $\mathrm{N}$ and $\mathrm{C}$ are summarized in Table 2. The values of $\mathrm{N}(=607,339.917)$ for DPE capped AgNPs is higher than that of $\mathrm{N}(=179,952.568)$ of CTAB-AgNPs, which might be due to the uncontrolled growth of AgNPs in absence of CTAB. Surfactant solubilized the reactants $\mathrm{Ag}^{+}$and ascorbic acid) into its small volume, enhances the nucleation and controlled the growth processes $[9,23]$. The DPE-AgNPs were unstable for long time storage, whereas CTAB-AgNPs are stable and can be used for the industrial and medicinal applications.

\subsection{Antibacterial activities of DPE-AgNPs}

It is well known that the metallic-silver and aqueous silver ions have been used to the treatment of human wounds and burns from the ancient time in the form of $\mathrm{AgNO}_{3}$. The AgNPs shows potential antimicrobial activities against human pathogens $[2,8]$. Therefore, antibacterial activities of AgNPs were determined against Gram-positive S. aureus and Gram-negative E. coli by using turbidity kinetic growth method [64]. The observed results are depicted graphically in Fig. 10 as absorbance-reaction time profiles. The reaction proceeds through an induction period (lag phase) followed by a growth as well as stationary phase, the nature of the kinetic curves depends on the concentration of AgNPs. The lag phase depends on the concentration of DPE-AgNPs. For S. aureus and E. coli, the rates were found to be $2.9,2.5,2.2,1.6 \times 10^{-1} \mathrm{~h}^{-1}$ and $3.7,3.3,3.1,2.9 \times 10^{-1} \mathrm{~h}^{-1}$ for $10.0,20.0,30.0$ and $40.0 \times 10^{-5} \mathrm{~mol} / \mathrm{L}$ DPE-AgNPs concentrations. The growth rates decrease with increasing the
NPs concentration. Our results are in good agreement to the observations of Sondi and Salopek-Sondi regarding to the effect of AgNPs on the growth of bacteria [64]. The growth rate killing of bacteria with gentamicin were found to be $3.6 \times 10^{-1} \mathrm{~h}^{-1}$ and $4.4 \times 10^{-1} \mathrm{~h}^{-1}$ for $S$. aureus and $E$. coli, respectively. The antibacterial activity of gentamicin is higher than that of DPE-AgNPs under our experimental conditions.

The role of metal ions in biological systems has been realized for a long time. Some metals are essential for the physiological activities of the cellular and subcellular functions [65]. Transition metals are the active constituents of various enzymes and proteins. Metal complex were used in tumor diagnosis and as anticancer agents. They are toxic at higher concentrations and disturbed the biological function of proteins and nucleic acids. Metal NPs were formed complex with protein cell wall bacteria, undergoes redox reaction, and released metal ions and reactive oxygen species inside the membrane cell wall. Cysteine formed complex with AgNPs, released $\mathrm{Ag}^{+}$ions and cysteine radical. Finally, cystine was formed after dimerization of generated radical, which changed the activities of protein cell wall. The decreases of growth rates with increasing AgNPs, can be rationalized due to the killing of bacterial cell activities.

\section{Conclusion}

We demonstrated the use of fresh and dry $C$. sinensis peel waste aqueous extract for the synthesis of AgNPs. UV-visible data revealed that the FPE and DPE have significant 

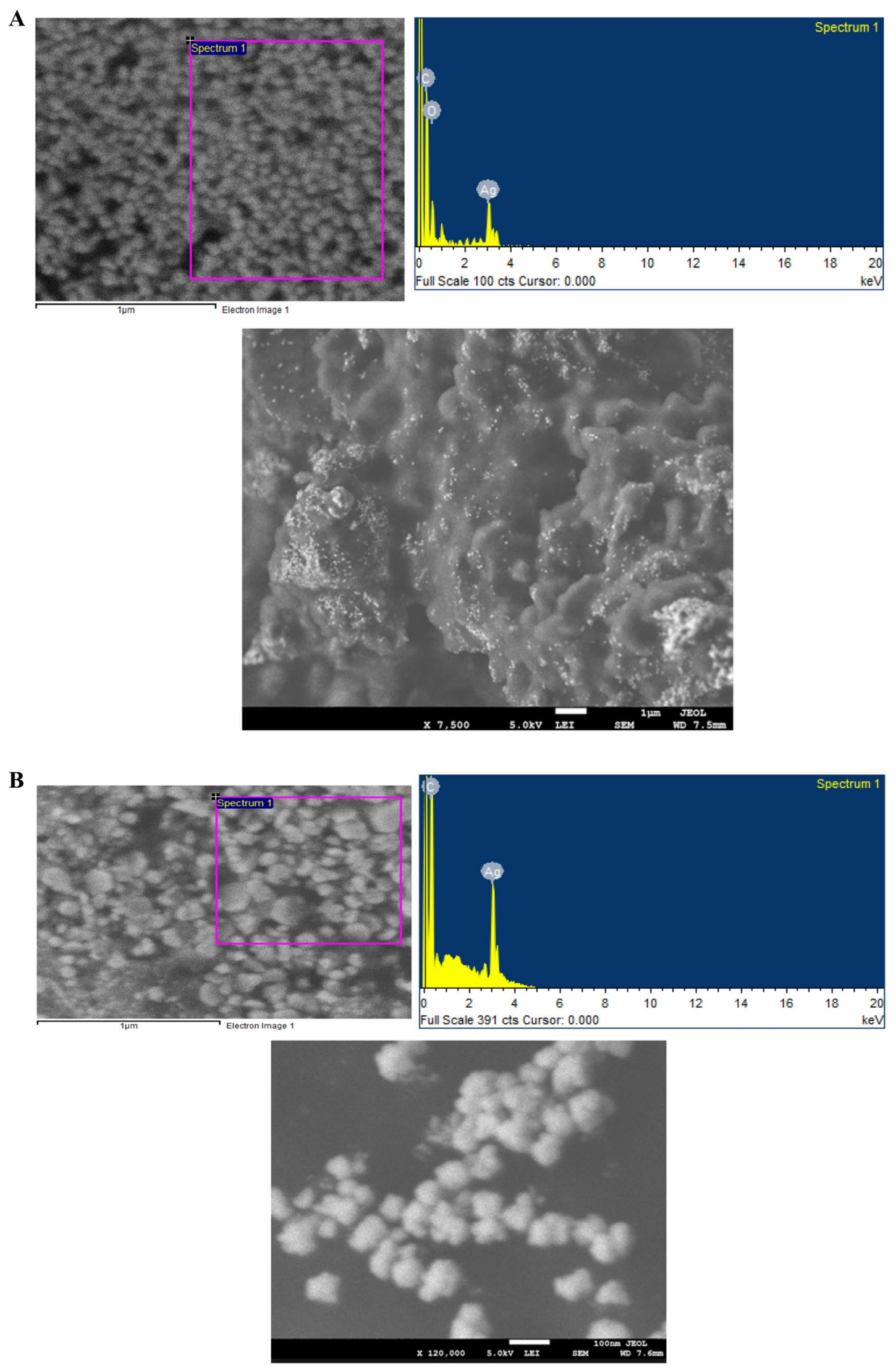

Fig. 6 EDX and SEM images of DPE-AgNPs (a), and CTAB-AgNPs. Reaction conditions: $\left[\mathrm{Ag}^{+}\right]=1.0 \mathrm{mM},[\mathrm{DPE}]=10 \%$, temperature $=30^{\circ} \mathrm{C}$ 


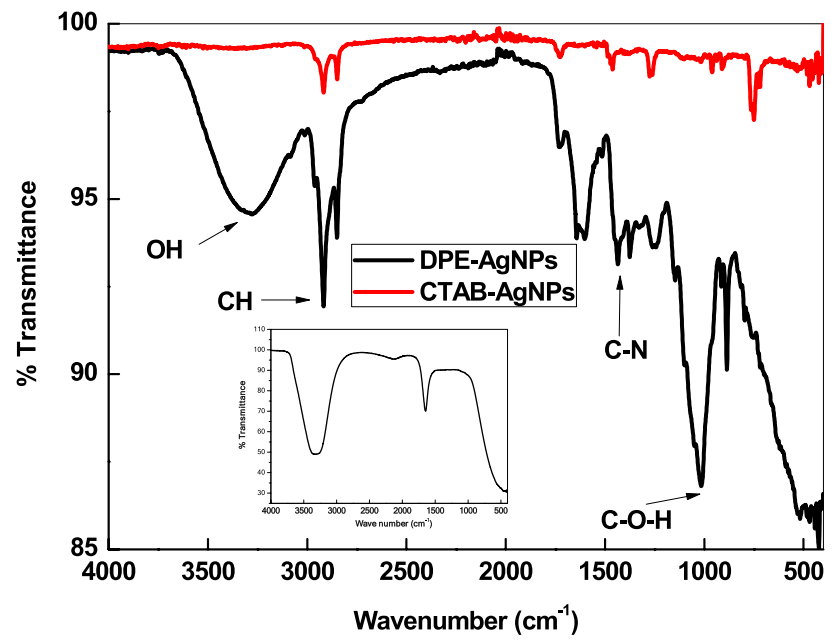

Fig. 7 FTIR spectra of DPE-AgNPs and CTAB-AgNPs. Inset: FTIR spectrum of pure DPE. Reaction conditions: $\left[\mathrm{Ag}^{+}\right]=1.0 \mathrm{mM}$, $[\mathrm{DPE}]=10 \%$, temperature $=30^{\circ} \mathrm{C}$

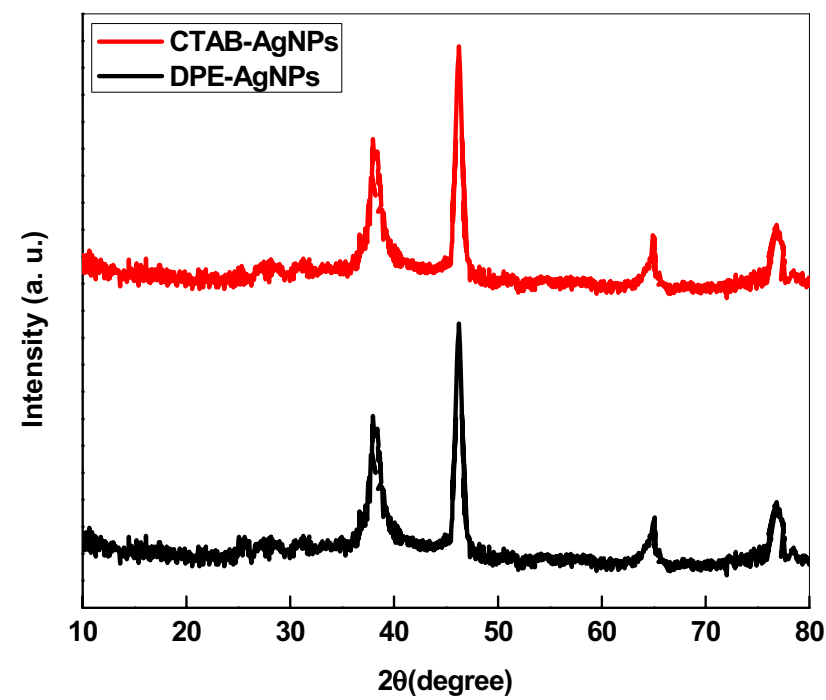

Fig. 8 XRD spectra of DPE-AgNPs and CTAB-AgNPs. Reaction conditions: $\left[\mathrm{Ag}^{+}\right]=1.0 \mathrm{mM},[\mathrm{DPE}]=10 \%$, temperature $=30^{\circ} \mathrm{C}$

impacts on the nucleation and growth processes. The stability depends on the concentration of extract, silver

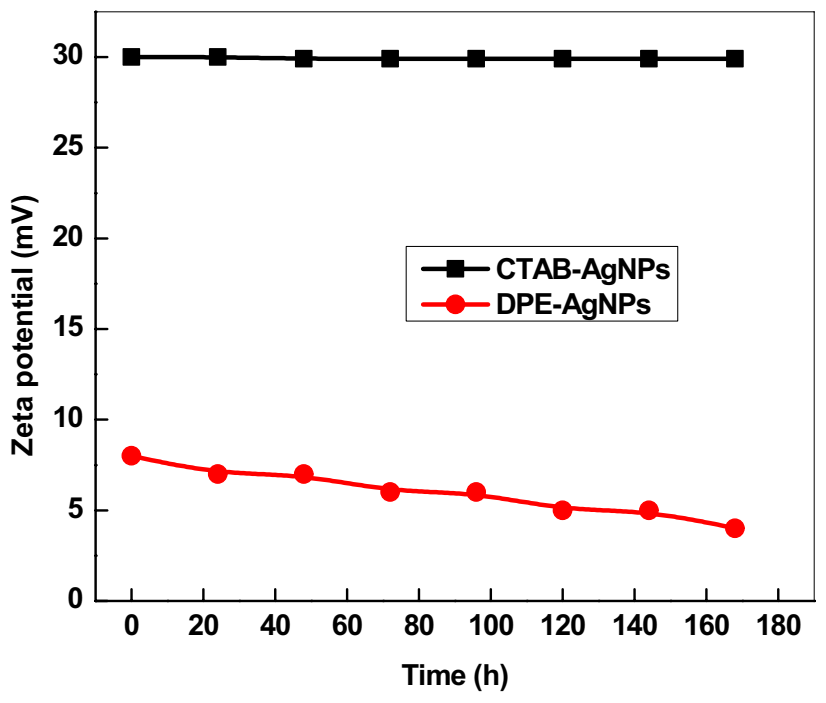

Fig. 9 Zeta potential of DPE-AgNPs and CTAB-AgNPs as a function of time. Particle charge was negative in both cases

Table 2 The values average diameter, N, and C of DPE-AgNPs and CTAB-AgNPs

\begin{tabular}{lll}
\hline Parameters & DPE-AgNPs & CTAB-AgNPs \\
\hline Average diameter $(\mathrm{nm})$ & 30 & 20 \\
$\mathrm{~N}$ & $607,339.917$ & $179,952.568$ \\
$\mathrm{C}(\mathrm{mol} / \mathrm{L})$ & $3.3 \times 10^{-4}$ & $1.11 \times 10^{-7}$ \\
\hline
\end{tabular}

ions, CTAB and SDS. Nucleation was fast for DPE with and without externally added stabilizers. The as-prepared AgNPs shows SPR band position at 418, 468 and $477 \mathrm{~nm}$ for CTAB, DPE and SDS. TEM images shows that the AgNPs are spherical and poly dispersed. The zeta potential, aggregation number, molar concentration is $-8 \mathrm{mV}$, $605,322.176,3.3 \times 10^{-4} \mathrm{~mL} / \mathrm{L}$ and $-30 \mathrm{mV}, 179,952.568$, $1.11 \times 10^{-7} \mathrm{~mol} / \mathrm{L}$, respectively, for DPE-AgNPs and CTABAgNPs, respectively. Antibacterial activities of DPE-AgNPs against $S$. aureus and $E$. coli were evaluated by turbidity method. The bacterial growth rate were decreases with increasing concentration of DPE-AgNPs. 

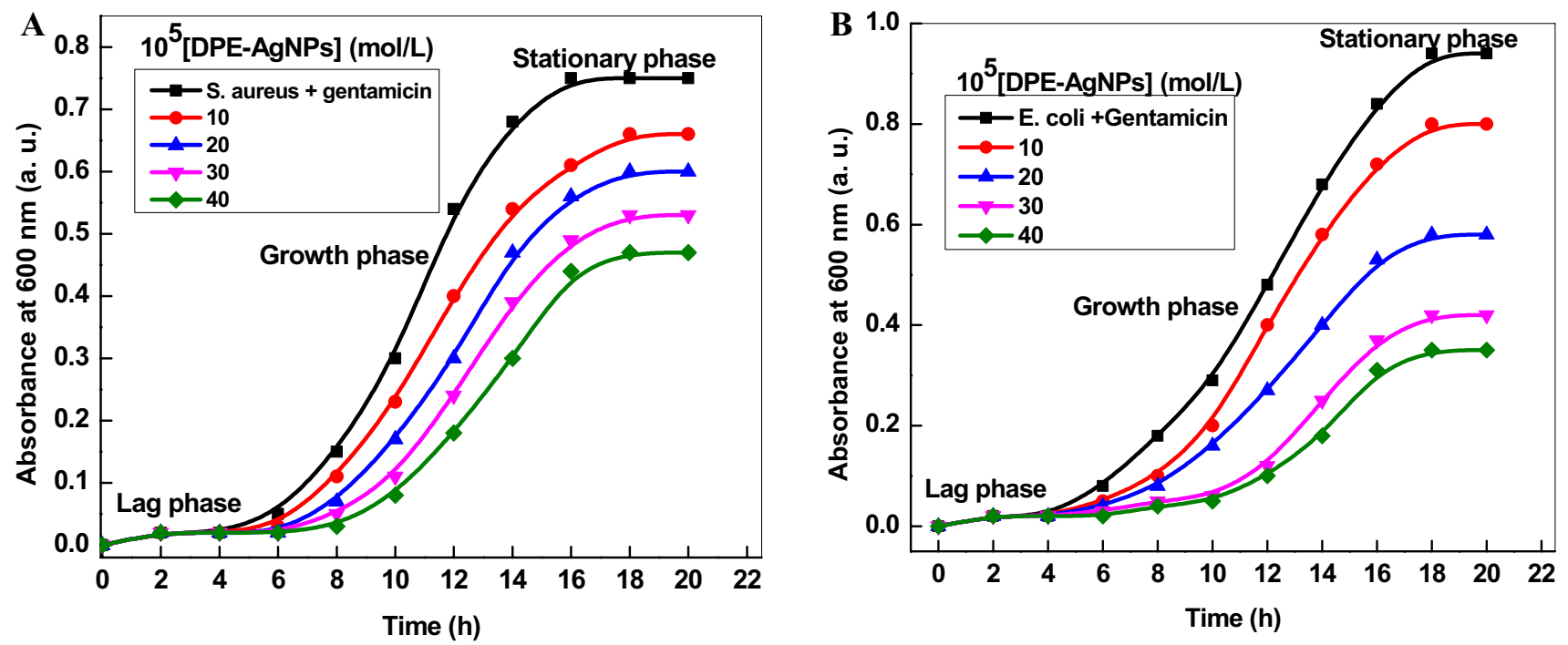

Fig. 10 The growth kinetic curves for the antibacterial activities of DPE-AgNPs against S. aureus (a) and E. coli (b) human pathogens as a function of AgNPs concentrations

\section{Compliance with ethical standards}

Conflict of interest None.

\section{References}

1. Bakshi MS (2009) Room a simple method of superlattice formation: step-by-step evaluation of crystal growth of gold nanoparticles through seed-growth method. Langmuir 25:12697-12705

2. Rai M, Yadav A, Gade A (2009) Silver nanoparticles as a new generation of antimicrobials. Biotechnol Adv 27:76-83

3. Balwe S, Shinde V, Rokade A, Park S, Jeong Y (2017) Green synthesis and characterization of silver nanoparticles (AgNPs) from extract of plant Radix Puerariae: an efficient and recyclable catalyst for the construction of pyrimido[1,2-b]indazole derivatives under solvent-free conditions. Catal Commun 99:121-126

4. Torres M, Gomez E, Fernandez M, Veglia A, Pacioni N (2019) Role of a cystine-based Gemini surfactant ligand in the synthesis of catalytic active silver nanoparticles. J Mol Liq 284:110-116

5. Mehta SK, Chaudhary S, Gradzielski M (2010) Time dependence of nucleation and growth of silver nanoparticles generated by sugar reduction in micellar media. J Colloid Interface Sci 343:447-453

6. Khabeeri OM, Al-Thabaiti SA, Khan Z (2020) Effects of ionic surfactants on the nucleation and growth of cyanidin 3,5-di-O-glucoside capped zerovalent iron nanoparticles. Colloid Interface Sci Commun 37:100272

7. Hosseinzadeh R, Sabzi R, Ghasemlu K (2009) Effect of cetyltrimethyl ammonium bromide (CTAB) in determination of dopamine and ascorbic acid using carbon paste electrode modified with tin hexacyanoferrate. Colloid Surf B Biointerfaces 68:213-217

8. Sharma VK, Yngard RA, Lin Y (2009) Silver nanoparticles: green synthesis and their antimicrobial activities. Adv Colloid Interface Sci 145:83-96

9. Bakshi MS (2018) Engineered nanomaterials growth control by monomers and micelles: from surfactants to surface active polymers. Adv Colloid Interface Sci 256:101-110
10. Pattanaik A, Venugopal R (2018) Investigation of adsorption mechanism of reagents (surfactants) system and its applicability in iron ore flotation-an overview. Colloid Interface Sci Commun 25:41-65

11. Yin Y, Li Z-Y, Zhong Z, Gates B, Xia Y, Venkateswaran S (2002) Synthesis and characterization of stable aqueous dispersions of silver nanoparticles through the Tollens process. J Mater Chem 12:522-527

12. Yao P, Zhang J, Xing T, Chen G, Tao R, Choo K (2018) Green synthesis of silver nanoparticles using grape seed extract and their application for reductive catalysis of Direct Orange 26. J Ind Eng Chem 58:74-79

13. Zaheer Z, Rafiuddin (2013) Bio-conjugated silver nanoparticles: from Ocimum sanctum and role of cetyltrimethyl ammonium bromide. Colloids Surf B Biointerfaces 108:90-94

14. Zaheer Z, Aazam ES, Kosa SA (2016) Effects of cationic and anionic micelles on the morphology of biogenic silver nanoparticles, and their catalytic activity for congo red. J Mol Liq 220:364-369

15. Hussain S, Al-Thabaiti SA, Khan Z (2014) Surfactant-assisted bioconjugated synthesis of silver nanoparticles (AgNPs). Bioprocess Biosyst Eng 37:1727-1735

16. Zaheer Z (2018) Biogenic synthesis, optical, catalytic, and in vitro antimicrobial potential of Ag-nanoparticles prepared using Palm date fruit extract. J Photochem Photobiol B Biol 178:584-592

17. Gopinath V, Ali DM, Priyadarshini S, Priyadharsshini NM, Thajuddin N, Velusamy P (2012) Biosynthesis of silver nanoparticles from Tribulus terrestris and its antimicrobial activity: a novel biological approach. Colloids Surf B Biointerfaces 96:69-74

18. Kosa SA, Zaheer Z (2019) Betanin assisted synthesis of betanin@ silver nanoparticles and their enhanced adsorption and biological activities. Food Chem 298:125014

19. Khan Z, Al-Thabaiti SA (2018) Green synthesis of zero-valent Fe-nanoparticles: catalytic degradation of rhodamine B, interactions with bovine serum albumin and their enhanced antimicrobial activities. J Photochem Photobiol B Biol 180:259-267

20. Ranoszek-Soliwoda K, Tomaszewska E, Małek K, Celichowski G, Orlowski P, Krzyzowska M, Grobelny J (2019) The synthesis of 
monodisperse silver nanoparticles with plant extracts. Colloids Surf B Biointerfaces 177:19-24

21. Ahmad A, Mukherjee P, Mandal D, Senapati S, Khan MI, Kumar R, Sastry M (2002) Enzyme mediated extracellular synthesis of CdS nanoparticles by the fungus, Fusarium oxysporum. J Am Chem Soc 124:12108-12109

22. Jayaprakash N, Vijaya JJ, Kaviyarasu K, Kombaiah K, Kennedy LJ, Ramalingam R, Munusamy MA, Al-Lohedan H (2017) Green synthesis of Ag nanoparticles using tamarind fruit extract for the antibacterial studies. J Photochem Photobiol B Biol 169:178-185

23. Bawazir WA, Alhogbi BG, Basaleh AS, Zaheer Z (2020) Capping action of ionic surfactants on the nucleation of lawsone- $\mathrm{Ag}^{+}$ redox system. J Mol Liq 309:113214

24. Al-Ghamdi AD, Zaheer Z, Aazam ES (2020) Sennoside A drug capped biogenic fabrication of silver nanoparticles and their antibacterial and antifungal activities. Saudi Pharm J 28:1035-1048

25. Torre I, Martin-Dominguez V, Acedos M, Esteban J, Santos VE, Ladero M (2019) Utilisation/upgrading of orange peel waste from a biological biorefinery perspective. Appl Microbiol Biotechnol 103(15):5975-5991

26. Prabasari I, Pettolino F, Liao M, Bacic A (2011) Pectic polysaccharides from mature orange (Citrus sinensis) fruit albedo cell walls: sequential extraction and chemical characterization. Carbohydr Polym 84:484-494

27. Balu AM, Budarin V, Shuttleworth PS, Pfaltzgraff LA, Waldron $K$, Luque R, Clark JH (2012) Valorisation of orange peel residues: waste to biochemicals and nanoporous materials. ChemSusChem 5:1694-1697

28. Amanulla A, Sundaram $\mathrm{R}$ (2019) Green synthesis of $\mathrm{TiO}_{2}$ nanoparticles using orange peel extract for antibacterial, cytotoxicity and humidity sensor applications. Mater Today Proc 8:323-331

29. Santos EB, Madalossi N, Sigoli FA, Mazali IO (2015) Silver nanoparticles: green synthesis, self-assembled nanostructures and their application as SERS substrates. New J Chem 39:2839-2846

30. Omran BA, Nassar HN, Fatthallah NA, Hamdy A, El-Shatoury EH, El-Gendy NS (2017) Waste upcycling of Citrus sinensis peels as a green route for the synthesis of silver nanoparticles. Energ Sources A 40:227-236

31. Kaviya S, Santhanalakshmi J, Viswanathan B, Muthumary J, Srinivasan K (2011) Biosynthesis of silver nanoparticles using Citrus sinensis peel extract and its antibacterial activity. Spectrochim Acta A 79:594-598

32. Kahrilas GA, Wally LM, Fredrick SJ, Hiskey M, Prieto AL, Owens JE (2013) Microwave-assisted green synthesis of silver nanoparticles using orange peel extract. ACS Sustain Chem Eng 2:367-376

33. Barros CHN, Cruz GCF, Mayrink W, Tasic L (2018) Bio-based synthesis of silver nanoparticles from orange waste: effects of distinct biomolecule coatings on size, morphology, and antimicrobial activity. Nanotechnol Sci Appl 11:1-14

34. M. I. Skiba, V. I. Vorobyova (2019), Synthesis of silver nanoparticles using orange peel extract prepared by plasmochemical extraction method and degradation of methylene blue under solar irradiation, Adv Mater Sci Eng, 2019, 8306015, 8 pages

35. Awad MA, Hendi AA, Ortashi KMO, Elradi DFA, Eisa NE, Al-lahieb LA, Al-Otiby SM, Merghani NM, Awad AAG (2014) Silver nanoparticles biogenic synthesized using an orange peel extract and their use as an anti-bacterial agent. Int J Phy Sci 9:34-40

36. Soto KM, Quezada-Cervantes CT, Hernández-Iturriaga M, LunaBárcenas G, Mendoza S (2019) Fruit peels waste for the green synthesis of silver nanoparticles with antimicrobial activity against foodborne pathogens. LWT 103:293-300

37. Rangayasami A, Kannan K, Joshi S, Subban M (2020) Bioengineered silver nanoparticles using Elytraria acaulis (L.f.) Lindau leaf extract and its biological applications. Biocatal Agric Biotechnol 27:101690

38. Aswini R, Meimozhi S, Tamilmozhi R, Kowsalya M, Murugesan S (2019) Green synthesis of silver nanoparticles using Ledebouria Revoluta bulb extract and its biological activity. In: Springer proceedings in materials. Proceedings of the international conference on nanomedicine (ICON-2019). Springer, Cham, pp 1-10

39. Gavade NL, Kadam AN, Suwarnkar MB, Ghodake VP, Garadkar KM (2015) Biogenic synthesis of multi-applicative silver nanoparticles by using Ziziphus jujuba leaf extract. Spectrochim Acta A 136:953-960

40. Gawade VV, Gavade NL, Shinde HM, Babar SB, Kadam AN, Garadkar KM (2017) Green synthesis of $\mathrm{ZnO}$ nanoparticles by using Calotropis procera leaves for the photodegradation of methyl orange. J Mater Sci Mater Electron 28:14033-14039

41. Khullar P, Goshisht MK, Moudgil L, Singh G, Mandial D, Kumar H, Ahluwalia GK, Bakshi MS (2017) Mode of protein complexes on gold nanoparticles surface: synthesis and characterization of biomaterials for hemocompatibility and preferential DNA complexation. ACS Sustain Chem Eng 5:1082-1093

42. Bakshi MS, Possmayer F, Petersen NO (2007) Role of different phospholipids in the synthesis of pearl-necklace-type gold-silver bimetallic nanoparticles as bioconjugate materials. J Phys Chem C 111:14113-14124

43. Radhika D, Kannan K, Neseraj AS, Namitha R (2019) Facile low-temperature synthesis and application of $\mathrm{La}_{0.85} \mathrm{Sr}_{0.15} \mathrm{CO}_{0.85} \mathrm{Fe}_{0.15} \mathrm{O}_{3-\delta}$ as superior cathode for LT-SOFCs using C-TAB as surfactant. Mater Res Innov 24(7):395-401. https://doi. org/10.1080/14328917.2019.1686858

44. Kannan K, Radhika D, Nesaraj AS, Ahmed MW, Namitha R (2019) Cost-effective method of Co-doped rare-earth-based ceria (Y-CGO) nanocomposite as electrolyte for LT-SOFCs using C-TAB as surfactant. Mater Res Innov 24(7):414-421. https://doi. org/10.1080/14328917.2019.1706032

45. Kannan K, Radhika D, Nesaraj AS, Revathi V, Sadasivuni KK (2020) A simple chemical precipitation of ceria based (Sm doped-CGO) nanocomposite: structural and electrolytic behaviour for LTSOFCs. SN Appl Sci 2:1220

46. Khan Z, Singh T, Hussain Jl, Al-Thabaiti SA, El-Mossalamy EH, Obaid AY (2013) Starch-directed green synthesis, characterization and morphology of silver nanoparticles. Colloids Surf B Biointerfaces 102:578-584

47. Albeladi AB, AL-Thabaiti SA, Khan Z (2020) Effect of CTAB on the surface resonance plasmon intensity of silver nanoparticles: stability and oxidative dissolution. J Mol Liq 302:112565

48. Kannangara I, Jayawardhana $Y$, Munasinghe $E$, Rajapakse $A$, Bandara A, Weerasooriya R, Jayarathna L (2020) Synthesis and characterization of nano zeolite-A with aid of sodium dodecyl sulfate (SDS) as particle size-controlling agent. Colloids Surf A Physicochem Eng Asp 589:124-427

49. Das S, Bououdina M, Manoharan C (2020) The influence of cationic surfactant $C T A B$ on optical, dielectric and magnetic properties of cobalt ferrite nanoparticles. J Ceramics Int B 46:11705-11716

50. Phuruangrat A, Keereesaensuk P-O, Thongtem S, Karthik K, Dumrongrojthanath P, Ekthammathat N, Thongtem T (2020) Synthesis and characterization Ag nanoparticles supported on $\mathrm{Bi}_{2} \mathrm{WO}_{6}$ nanoplates for enhanced visible-light-driven photocatalytic degradation of rhodamine B. J Inorg Organomet Polym Mater 30:1033-1040

51. Phuruangrat $A$, Keereesaensuk P-O, Thongtem S, Ekthammathat $N$, Dumrongrojthanath P, Karthik K, Thongtem T (2020) Synthesis of $\mathrm{Ag} / \mathrm{Bi}_{2} \mathrm{MoO}_{6}$ nanocomposites using $\mathrm{NaBH}_{4}$ as reducing agent for enhanced visible-light-driven photocatalysis of rhodamine B. J Inorg Organomet Polym Mater 30:322-329 
52. Klein BP, Perry AK (1982) Ascorbic acid and vitamin A activity in selected vegetables from different geographical areas of the United States. J Food Sci 47:941-945

53. Sigmann SB, Wheeler DE (2004) Quantitative determination of citric and ascorbic acid in powdered drink mixes. J Chem Educ 81:1479-1481

54. Miller GL (1959) Use of dinitrosalicilic acid reagent for determination of reducing sugars. Anal Chem 31:426-428

55. Pal S, Tak YK, Song JM (2007) Does the antibacterial activity of silver nanoparticles depend on the shape of the nanoparticle? A study of the gram-negative bacterium Escherichia coli. Appl Environ Microbiol 73:1712-1720

56. Rezzadori K, Benedetti S, Amante ER (2012) Proposals for the residues recovery: orange waste as raw material for new products. Food Bioprod Process 90:606-614

57. Guimaraes R, Barros L, Barreira JCM, Sousa MJ, Carvalho AM, Ferreira ICFR (2010) Targeting excessive free radicals with peels and juices of citrus fruits: grapefruit, lemon, lime and orange. Food Chem Toxicol 48:99-106

58. Tabart J, Kevers C, Pincemailb J, Defraigne J-O, Dommes J (2010) Evaluation of spectrophotometric methods for antioxidant compound measurement in relation to total antioxidant capacity in beverages. Food Chem 120:607-614

59. Tascioglu S (1996) Micellar solutions as reaction media. Tetrahedron 52:11113-11152
60. Goia DV, Matijevic E (1998) Preparation of monodispersed metal particles. New J Chem 22:1203-1215

61. Henglein A (1993) Physicochemical properties of small metal particles in solution: "microelectrode" reactions, chemisorption, composite metal particles, and the atom-to metal transition. J Phys Chem 97:5457-5471

62. Zapata B, Balmaseda J, Fregoso-Israel E, Torres-Garcia E (2009) Thermo-kinetics study of orange peel in air. JTherm Anal Calorim 98:309-315

63. Melendrez MF, Cardenas G, Arbiol J (2010) Synthesis and characterization of gallium colloidal nanoparticles. J Colloid Interface Sci 346:279-287

64. Sondi I, Salopek-Sondi B (2004) Silver nanoparticles as antimicrobial agent: a case study on E. coli as a model for Gram-negative bacteria. J Colloid Interface Sci 275:177-182

65. Sigel H, Sigel A (eds) (2004) Metal complexes in tumor diagnosis and as anticancer agents. Metal ions in biological systems, vol 42. Marcel Dekker, Inc, New York

Publisher's Note Springer Nature remains neutral with regard to jurisdictional claims in published maps and institutional affiliations. 